\title{
PETA DISTRIBUSI DAN RESISTENSI Acinetobacter baumannii DARI SPESIMEN KLINIK DI RSUD DR. ZAINOEL ABIDIN TAHUN 2018
}

\author{
Wilda Mahdani ${ }^{1,2,{ }^{*}}$, Zinatul Hayati ${ }^{1,2}$, Teuku Yusriadi ${ }^{3,4}$ \\ ${ }^{1}$ Bagian Mikrobiologi, Fakultas Kedokteran, Universitas Syiah Kuala, Darussalam, Banda Aceh 23111, Indonesia \\ ${ }^{2}$ Laboratorium Mikrobiologi Klinik, Rumah Sakit Umum Dr. Zainoel Abidin, Banda Aceh 23126, Indonesia \\ ${ }^{3}$ Bagian Bedah, Fakultas Kedokteran, Universitas Syiah Kuala, Darussalam, Banda Aceh 23111, Indonesia \\ ${ }^{4}$ Bagian Bedah, Divisi Bedah Anak Rumah Sakit Umum Dr. Zainoel Abidin, Banda Aceh 23126, Indonesia
}

Corresponding author : wildamahdani@unsyiah.ac.id

\begin{abstract}
Abstrak
Kemampuan hidup Acinetobacter baumannii pada berbagai keadaan dikombinasikan dengan resistensi berkaitan erat dengan Healthcare Associated Infections (HAIs). Kemunculan strain resisten telah banyak dilaporkan. Penelitian ini bersifat observasional deskriptif. Pemeriksaan spesimen klinik dilakukan di Laboratorium Mikrobiologi Klinik RSUD dr. Zainoel Abidin Banda Aceh. Isolat Acinetobacter baumannii dikumpulkan, dilakukan uji kepekaan serta dinilai tingkat resistensinya. Angka insidensi Acinetobacter baumannii adalah 4,6\% yang dominan terisolasi dari spesimen sputum. Strain resisten sangat umum dijumpai pada ruang rawat intensif, ruangan non intensif memiliki lebih banyak strain susceptible. Strain MDR menunjukkan kepekaan terhadap amikacin, trimethoprim-sulfamethoxazole, tobramycin, ampicillin-sulbactam, dan meropenem. Acinetobacter baumannii strain XDR hanya menunjukkan kepekaan yang masih baik terhadap amikacin. Data epidemiologi resistensi antibiotik adalah komponen utama Program Pengendalian Resistensi Antibiotik di rumah sakit.
\end{abstract}

Kata kunci : acinetobacter baumannii, healthcare associated infections, resistensi antimikroba

\section{Distribution And Resistance Map acinetobacter baumannii From Clinical Specimens In Rsud Dr. Zainoel Abidin In 2018}

\begin{abstract}
The survival ability of Acinetobacter baumannii in various circumstances combined with its resistance is closely related to Healthcare Associated Infections (HAIs). The emergence of resistant strains has been widely reported. This research is an observational descriptive. Clinical specimen examination was carried out at the Clinical Microbiology Laboratory of RSUD dr. Zainoel Abidin Banda Aceh. Acinetobacter baumannii isolates were collected, susceptibility test and resistance level were assessed. The incidence rate of Acinetobacter baumannii is $4.6 \%$, which is predominantly isolated from sputum specimens. Resistant strains are commonly found in intensive care rooms, non-intensive rooms have more susceptible strains. MDR strains show susceptibility to amikacin, trimethoprim-sulfamethoxazole, tobramycin, ampicillin-sulbactam, and meropenem. Acinetobacter baumannii XDR strain only shows a good susceptibility to amikacin. Epidemiological data on antibiotic resistance is a major component of the Hospital's Antibiotic Stewardship Program.
\end{abstract}

Keywords : acinetobacter baumannii, healthcare associated infections, antimicrobial resistance 


\section{PENDAHULUAN}

Healthcare Associated Infections (HAIs) adalah masalah kesehatan penting. ${ }^{1}$ Kemunculan dan transmisi Acinetobacter resisten terhadap antimikroba berkaitan erat dengan HAIs. $^{2}$ Mekanisme utama untuk mengatasi infeksi adalah penggunaan antibiotik. Namun, bila antibiotik sudah tidak efektif karena resistensi bakteri, manajemen infeksi yang efisien tidak akan tercapai. $^{3}$

Barrie dan Gorman menyatakan bahwa Acinetobacter baumannii menjadi ancaman dunia kesehatan, bahayanya sebanding dengan Methicillin Resistant Staphylococcus aureus (MRSA). ${ }^{4}$ Acinetobacter baumannii memiliki virulensinya yang tinggi. ${ }^{5}$ Acinetobacter baumannii dapat bertahan hidup dalam jangka waktu yang lama dalam kondisi lembab maupun kering. ${ }^{6}$ Strain resisten telah banyak dilaporkan kemunculannya di berbagai penjuru dunia. ${ }^{7,8}$ Beberapa laporan menunjukkan bahwa strain MDR sering dikaitkan dengan banyak wabah di seluruh Eropa dan sekitarnya. ${ }^{9}$

Penularan infeksi Acinetobacter baumannii diperantarai oleh kontaminasi lingkungan. ${ }^{10}$ Bakteri ini menyebabkan spektrum infeksi luas meliputi pneumonia, bakteremia, meningitis, infeksi saluran kemih dan infeksi luka. ${ }^{2}$ Acinetobacter baumannii memiliki ketahanan dan kemampuan memperoleh resistensi jauh lebih cepat daripada bakteri Gram negatif lainnya. ${ }^{2}$ Prevalensi penggunaan antimikroba yang tinggi juga berhubungan dengan resistensi yang diamati secara signifikan lebih tinggi. ${ }^{11}$

Sejalan Permenkes Nomor 8 Tahun 2015 tentang Program Pengendalian Resistensi Antibiotik, sangat penting untuk memiliki data epidemiologi resistensi antibiotik di pusat-pusat pelayanan medis. Surveilans di rumah sakit adalah komponen kunci yang relevan dan kontinuitasnya harus didukung. ${ }^{12}$

Pengumpulan data spesifik seperti epidemiologi MDR dan XDR Acinetobacter baumannii ini sangat diperlukan untuk mengevaluasi intervensi yang mungkin dituangkan dalam kebijakan manajemen infeksi di rumah sakit, khususnya di RSUD dr. Zainoel Abidin.

Tujuan penelitian ini adalah untuk memperoleh data epidemiologi tentang peta distribusi, tingkat resistensi dan pola kepekaan bakteri Acinetobacter baumannii yang terisolasi dari seluruh spesimen klinik pasien yang dirawat di RSUD dr. dr. Zainoel Abidin.

\section{TINJAUAN PUSTAKA}

Morfologi dan Fisiologi Acinetobacter baumanii 
Acinetobacter baumannii adalah batang coccobacillary gram negatif tidak memfermentasi laktosa, aerobik, terdistribusi secara luas di tanah dan udara. Acinetobacter baumannii dapat tumbuh di berbagai temperatur, $\mathrm{pH}$ dan mampu menggunakan berbagai macam substrat untuk pertumbuhan. ${ }^{2,13}$

Acinetobacter spp. telah diisolasi dari semua spesimen manusia yang dikultur. Acinetobacter spp. Merupakan bagian dari flora bakteri pada kulit, terutama di daerah lembab seperti kulit, pangkal paha, dan jari kaki. Sejumlah 43\% orang dewasa sehat memiliki kolonisasi pada kulit dan selaput lendir. Spesies yang paling banyak diisolasi meliputi A. lwoffii, A. johnsonii, A. junii, dan spesies genom Acinetobacter. Menariknya, A. baumannii, jarang ditemukan pada kulit dan kotoran manusia sehat. ${ }^{14,15}$

\section{Acinetobacter baumanii Sebagai Penyebab Utama Infeksi Nosokomial}

Kemampuan hidup Acinetobacter baumannii pada berbagai keadaan dikombinasikan dengan resistensi intrinsiknya terhadap banyak agen antimikroba, berkontribusi pada ketahanan mikroorganisme dan memungkinkannya menyebar di lingkungan rumah sakit. ${ }^{16}$ Infeksi Acinetobacter baumannii bisa berakibat fatal pada mereka dengan kekebalan tubuh suboptimal.

Infeksi nosokomial yang disebabkan oleh bakteri ini banyak ditemui pada pasien dirawat di unit perawatan intensif. Pasien kritis dengan selang-selang kateter dianggap sebagai kelompok paling berisiko untuk terinfeksi. Inefisiensi program pengendalian infeksi, penggunaan antibiotik tidak rasional serta beberapa alasan lainnya, bertanggung jawab dalam kemunculan Multidrug Resistant Organism (MDRO) yang sulit dieradikasi dengan antibiotik. ${ }^{17}$

\section{Resistensi Antimikroba}

Resistensi antibiotik didefinisikan sebagai kegagalan terapi penyakit infeksi karena bakteri sudah menjadi kebal terhadap antibiotik. Penyebab resistensi bervariasi, namun sering diasumsikan sebagai akibat dari terapi antimikroba awal yang tidak tepat, meliputi pemberian dosis subterapeutik, penggunaan obat berlebihan, abbreviated atau interrupted treatment, dan penetrasi ke jaringan yang tidak optimal. ${ }^{6}$

Penyakit infeksi oleh kuman yang kebal semakin sulit diobati, dokter terpaksa meresepkan antibiotik lini kedua atau bahkan ketiga saat pengobatan lini pertama tidak berhasil. Hal ini berdampak merugikan seperti beban biaya, masa rawatan lebih panjang bahkan kematian. ${ }^{18}$ Antimikroba ini suatu saat mungkin saja tidak dapat lagi menyembuhkan infeksi dan epidemi infeksi bakteri yang mematikan akan merajalela. ${ }^{19}$

Perkembangan Resistensi Acinetobacter baumannii 
Antibiotik golongan penicillin dan sulfa telah ditinggalkan karena begitu banyak bakteri patogen telah resisten. ${ }^{20}$ Penemuan antibiotik baru semakin langka. Hal ini bertolak belakang dengan kemunculan mikroorganisme multiresisten yang semakin banyak dilaporkan. ${ }^{18}$

Istilah yang berbeda seperti 'Multidrug Resistant (MDR)', 'Extensive Drug Resistant (XDR),' dan 'Pandrug Resistant (PDR)' telah digunakan dengan berbagai definisi untuk menggambarkan tingkat resistensi antimikroba antara Acinetobacter spp. ${ }^{2}$ Penilaian reistensi dalam penelitian ini mengacu pada panduan European Centre for Disease Prevention and Control (eCDC). ${ }^{21}$

\section{METODE PENELITIAN}

Penelitian ini bersifat observasional deskriptif, dilaksanakan di RSUD dr. Zainoel Abidin Banda Aceh. Pemeriksaan spesimen klinik yang dikirim dari ruang rawat dilakukan di Laboratorium Mikrobiologi Klinik. Penelitian ini dilakukan selama 6 bulan, mulai dari bulan April hingga September 2018. Seluruh spesimen klinik yang masuk ke Laboratorium Mikrobiologi Klinik RSUDZA dan terisolasi Acinetobacter baumannii dikumpulkan dan dilakukan uji kepekaan serta dinilai pola tingkat resistensinya, apakah NonMDR, MDR atau XDR. Spesimen diisolasi, identifikasi dan diuji kepekaan antimikroba dengan menggunakan Sistem Metode Vitek 2 (bioMérieux, France) yang dikonfirmasi dengan pedoman CLSI. ${ }^{22}$ Penentuan level resistensi Acinetobacter baumannii menggunakan panduan European Centre for Disease Prevention and Control (eCDC). ${ }^{21}$

\section{HASIL PENELITIAN DAN PEMBAHASAN}

Insidensi Acinetobacter baumannii dari spesimen klinik di RSUD dr. Zainoel Abidin adalah sebesar 4,6\%. Total isolat yang diperiksa dalam periode tersebut sebanyak 6997, dimana 323 diantaranya merupakan Acinetobacter baumannii.

Acinetobacter baumannii berasal dari berbagai spesimen pasien. Pasien Laki-laki 198 orang $(61,3 \%)$ dan perempuan 125 orang (38,7\%). Hasil ini menunjukkan infeksi Acinetobacter baumannii nosokomial lebih sering pada pria daripada wanita. Rasio laki-laki : perempuan adalah 1,6 : 1. Yuan dan Deng dalam penelitian mereka juga menemukan bahwa insidensi Acinetobacter baumannii yang meningkat secara signifikan pada pria dibandingkan dengan wanita, dengan rasio pria-wanita secara keseluruhan sebesar $2,8: 1^{23}$

Rentang umur pasien berkisar antara 0 sampai 89 tahun, rata-rata 44,3 (standar deviasi 22,4). Penelitian Xiao menunjukkan bahwa tidak ada perbedaan signifikan antara kelompok umur pasien yang terinfeksi oleh Acinetobacter baumannii. ${ }^{24}$ Infeksi dapat terjadi pada semua 
kelompok umur. Mortalitas pada pasien dengan infeksi Acinetobacter baumannii adalah 74,1\%. Analisis multivariat menunjukkan bahwa syok septik dan usia tua ( $\geq 65$ tahun) secara bermakna berhubungan dengan risiko kematian pada pasien dengan infeksi Acinetobacter baumannii. ${ }^{25}$

Isolat Acinetobacter baumannii paling banyak didapatkan dari spesimen sputum, sejumlah 181(56\%) dari seluruh jumlah isolat. Sampel sputum dapat berasal dari sputum spontan, sputum terinduksi maupun aspirat Enditracheal Tube (ETT) pada pasien yang menggunakan ventilator.



Gambar 1. Diagram distribusi Acinetobacter baumannii berdasarkan spesimen klinik di RSUD dr. Zainoel Abidin.

Isolat Acinetobacter baumannii paling banyak didapatkan dari spesimen sputum terutama berasal dari ICU. Penelitian Jung mengidentifikasi ventilasi mekanik sebagai faktor risiko potensial untuk pneumonia dan bakteremia terkait ventilator. ${ }^{26}$ Hal ini menjelaskan mengapa isolat Acinetobacter baumannii paling sering ditemukan di saluran pernapasan.
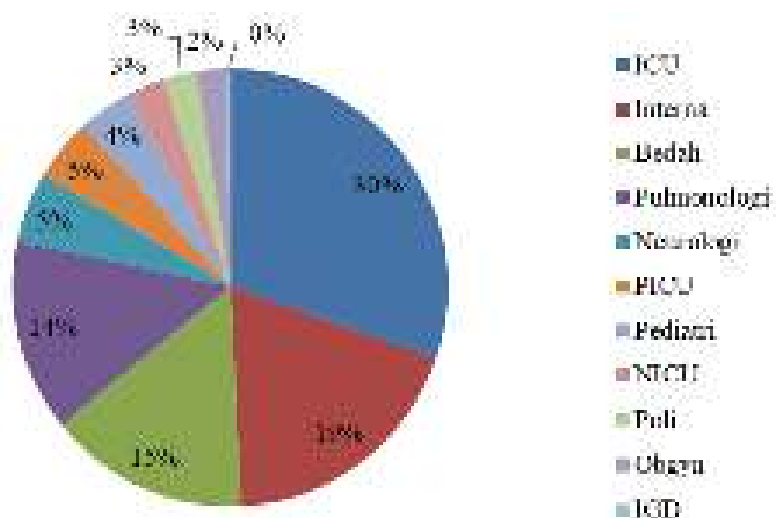

Gambar 2. Pola distribusi Acinetobacter baumannii berdasarkan ruangan di RSUD dr. Zainoel Abidin 
ICU merupakan ruang rawat yang paling banyak menyumbang sampel Acinetobacter baumannii yaitu sebanyak 98 isolat (30,3\%), disusul oleh ruang rawat interna $61(18,9 \%)$, bedah 48 (14,9\%), paru 46 (14,2\%), neurologi 17 (5,3\%), PICU 15 (4,6\%), pediatri 13 (4\%), NICU 9 (2,8\%), Poliklinik Rawat Jalan 8 (2,5\%), ruang rawat obgyn 7 (2,2\%) dan IGD menyumbang satu sampel (0,3\%). Uwingabiye melaporkan bahwa 8,4\% dari pasien ICU akan mengalami infeksi Acinetobacter baumannii. Analisis regresi mengidentifikasi faktor risiko independen yang didapat di ICU yaitu masa inap ICU $\geq 14$ hari (odds rasio $(\mathrm{OR})=6,4$ ), penggunaan kateter vena sentral sebelumnya $(\mathrm{OR}=18)$, penggunaan mekanik ventilasi sebelumnya $(\mathrm{OR}=9.5)$, durasi prosedur invasif $\geq 7$ hari $(\mathrm{OR}=7.8)$, paparan sebelumnya terhadap imipenem $(\mathrm{OR}=9.1)$, paparan sebelumnya terhadap amikacin $(\mathrm{OR}=5.2)$, paparan sebelumnya terhadap politerapi antibiotik $(\mathrm{OR}=11.8)$ dan paparan sebelumnya terapi kortikosteroid $(\mathrm{OR}=5) .{ }^{25}$

Tabel 1. Tabulasi silang pola distribusi isolat Acinetobacter baumannii berdasarkan ruang perawatan dan jenis spesimen di RSUD dr. Zainoel Abidin

\begin{tabular}{ccccccccccccccc}
\hline \multirow{2}{*}{ Ruang } & \multicolumn{2}{c}{ Darah } & \multicolumn{2}{c}{ CVC } & \multicolumn{2}{c}{ Pus } & \multicolumn{2}{c}{ Sputum } & \multicolumn{2}{c}{ Urin } & \multicolumn{3}{c}{ Cairan } \\
tubuh lain & \multicolumn{2}{c}{ Total } \\
\hline & $\mathrm{n}$ & $\%$ & $\mathrm{n}$ & $\%$ & $\mathrm{n}$ & $\%$ & $\mathrm{n}$ & $\%$ & $\mathrm{n}$ & $\%$ & $\mathrm{n}$ & $\%$ & $\mathrm{n}$ & $\%$ \\
\hline ICU & 22 & 22 & 7 & 7 & 0 & 0 & 69 & 70 & 0 & 0 & 0 & 0 & 98 & 100 \\
Obgyn & 0 & 0 & 0 & 0 & 1 & 14 & 4 & 57 & 1 & 14 & 1 & 14 & 7 & 100 \\
Bedah & 7 & 15 & 0 & 0 & 22 & 46 & 15 & 31 & 1 & 2 & 3 & 6 & 48 & 100 \\
Interna & 10 & 16 & 2 & 3 & 12 & 20 & 23 & 38 & 12 & 20 & 2 & 3 & 61 & 100 \\
Pulmonologi & 0 & 0 & 0 & 0 & 0 & 0 & 42 & 91 & 1 & 2 & 3 & 7 & 46 & 100 \\
PICU & 2 & 13 & 0 & 0 & 0 & 0 & 13 & 87 & 0 & 0 & 0 & 0 & 15 & 100 \\
NICU & 5 & 56 & 0 & 0 & 2 & 22 & 0 & 0 & 0 & 0 & 2 & 22 & 9 & 100 \\
Neurologi & 0 & 0 & 0 & 0 & 2 & 12 & 11 & 65 & 4 & 24 & 0 & 0 & 17 & 100 \\
Poli & 0 & 0 & 0 & 0 & 3 & 38 & 2 & 25 & 1 & 13 & 2 & 25 & 8 & 100 \\
Pediatri & 4 & 31 & 0 & 0 & 1 & 8 & 1 & 8 & 6 & 46 & 1 & 8 & 13 & 100 \\
IGD & 0 & 0 & 0 & 0 & 0 & 0 & 1 & 100 & 0 & 0 & 0 & 0 & 1 & 100 \\
\hline Total & 50 & 15 & 9 & 3 & 43 & 13 & 181 & 56 & 26 & 8 & 14 & 4 & 323 & 100 \\
\hline
\end{tabular}

Spesimen sputum menjadi dominasi sampel dari ruangan ICU, didapatkan 69 isolat Acinetobacter baumannii (70\%). Pada bagian bedah dan poliklinik Acinetobacter baumannii paling banyak didapatkan dari sampel pus, masing-masing $46 \%$ dan $38 \%$. Isolat dari spesimen urin mendominasi di ruang rawat pediatri sebesar $46 \%$ serta spesimen darah di ruang NICU $(56 \%)$.

Meskipun sputum merupakan sampel terbanyak namun proporsinya hanya $16,7 \%$. Proporsi tertinggi Acinetobacter baumannii justru didapatkan dari kultur darah CVC. Serupa dengan temuan Jung terkait penggunaan kateter vena sentral juga dilaporkan secara independen 
berhubungan dengan bakteremia MDR Acinetobacter baumannii dalam penelitian di Korea. Kateter sentral merupakan sumber penting infeksi aliran darah. Penyisipan kateter ke dalam pembuluh darah sentral mencetuskan kolonisasi mikroorganisme, mengarah ke pembentukan biofilm sehingga menyebabkan infeksi lokal atau sistemik dalam 24 jam dari penyisipannya.

Kemampuannya membentuk biofilm merupakan salah satu mekanisme penting dalam munculnya strain Acinetobacter baumannii resisten. Isolat klinis telah diamati memiliki kemampuan kuat untuk membentuk biofilm. ${ }^{27,28}$ Pembentukan biofilm menjadi lebih hebat dalam menanggapi konsentrasi antibiotik subinhibitori sebagai konsekuensi penggunaan antibiotik tidak rasional. $^{29}$

Penelitian lainnya melaporkan bahwa penggunaan prosedur invasif selama 7 hari atau lebih meningkatkan risiko akuisisi Acinetobacter baumannii hampir 7 kali lipat. Temuan ini menunjukkan perlunya penyapihan perangkat medis invasif sesegera mungkin untuk mencegah perkembangan infeksi Acinetobacter baumannii. ${ }^{25}$

Tabel 2. Tingkat resistensi Acinetobacter baumannii di RSUD dr. Zainoel Abidin.

\begin{tabular}{lccc}
\hline & Resistensi & Frekuensi & Persentase (\%) \\
\hline Susceptible & 97 & 30,0 \\
MDR & 90 & 27,9 \\
XDR & 136 & 42,1 \\
\hline Total & 323 & 100 \\
\hline
\end{tabular}

Angka resistensi Acinetobacter baumannii di RSUD dr. Zainoel Abidin dapat dilihat pada tabel 2. Pembagian level resistensi tidak dapat menentukan strain Pan Drug Resistant (PDR) dikarenakan keterbatasan sumber daya. Acinetobacter baumannii strain susceptible didapatkan sebanyak 97 isolat (30\%), Multi Drug Resistant (MDR) sebanyak 90 isolat (27,9\%) dan tingkat Extensively Drug Resistant (XDR) merupakan yang paling dominan sebanyak 136 isolat $(42,1 \%)$. 


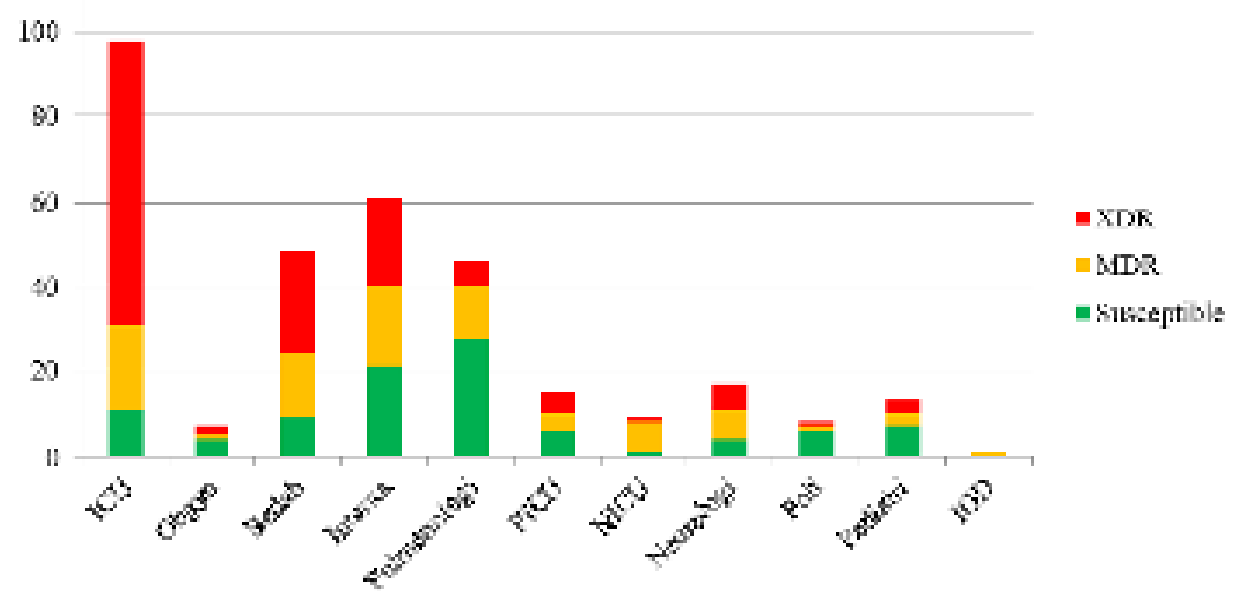

Gambar 3. Pola distribusi Acinetobacter baumannii MDR dan XDR berdasarkan ruangan di RSUD dr. Zainoel Abidin.

ICU merupakan ruangan yang didominasi oleh strain resisten. Sebanyak 67 isolat $(68,4 \%)$ merupakan strain XDR. Diantara strain XDR sangat mungkin terdapat pula strain PDR, hal ini dapat dikonfirmasi melalui penambahan uji kepekaan terhadap antimikroba yang belum tersedia. Ruang rawat intensif menyumbang angka Acinetobacter baumannii XDR terbesar. Strain yang susceptible masih mendominasi pada ruang rawat non-intensif.

Penghitungan persentase sensitivitas yaitu dengan cara menjumlahkan isolat yang sensitif dan intermediet terhadap antibiotik tertentu dan dibagi dengan jumlah seluruh uji yang valid terhadap antibiotik tersebut, lalu dikonversi dalam persen. Pola kepekaan bakteri Acinetobacter baumannii terhadap antibiotik di RSUD dr. Zainoel Abidin dapat diamati pada gambar 4.

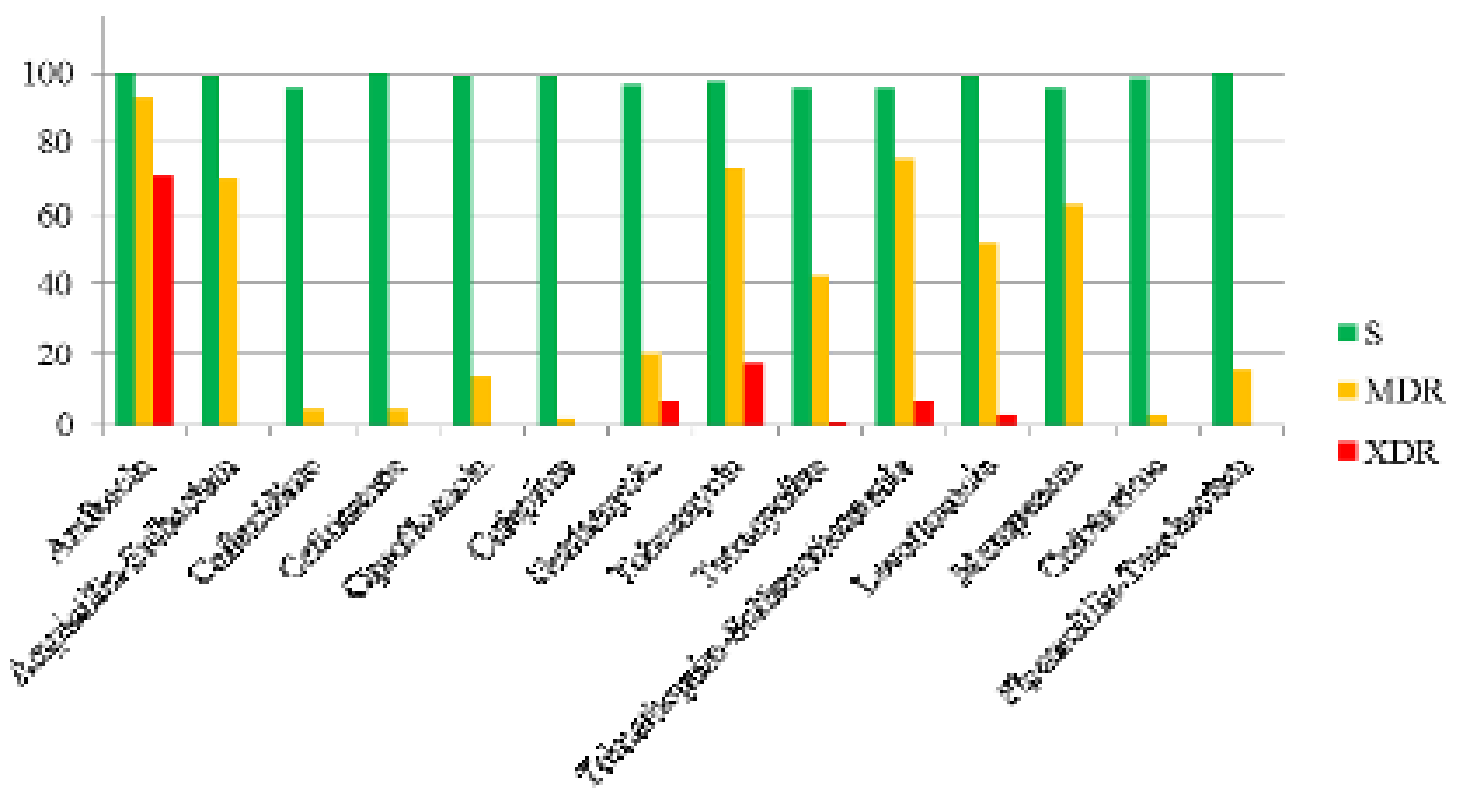

Gambar 4. Pola kepekaan Acinetobacter baumannii terhadap antibiotik di RSUD dr. Zainoel Abidin. 
Acinetobacter baumannii strain susceptible, masih menunjukkan kepekaan yang tinggi terhadap berbagai antibiotik uji. Strain MDR menunjukkan kepekaan yang baik terhadap amikacin (93\%), trimethoprim-sulfamethoxazole (75,3\%), tobramycin (73,3\%), ampicillinsulbactam (70\%), dan meropenem (62,5\%). Acinetobacter baumannii strain XDR hanya menunjukkan kepekaan yang masih baik terhadap amikacin (70,6\%). Amikacin merupakan suatu antibiotik golongan aminoglikosida yang memiliki efek nefrotoksisitas, sehingga penggunaan amikacin pada pasien dengan gangguan fungsi ginjal harus dibawah pengawasan.

Perlu untuk dipahami bahwa pola kepekaan dari suatu rumah sakit akan berbeda dengan pola di rumah sakit yang lain. Demikian juga halnya berbeda dari waktu ke waktu. Pola kepekaan terbaru dapat menjadi acuan dalam penatalaksanaan penyakit infeksi dan penyusunan kebijakan dalam pencegahan dan pengendalian infeksi di rumah sakit.

\section{KESIMPULAN}

Angka insidensi Acinetobacter baumannii periode April hingga September 2018 di RSUD dr. Zainoel Abidin adalah 4,6\%. Proporsi isolat tertinggi didapatkan dari spesimen CVC walaupun secara umum paling banyak terisolasi dari spesimen sputum. Ruangan yang menyumbang paling banyak Acinetobacter baumannii adalah ICU, dimana didominasi oleh strain XDR. Strain resisten sangat umum dijumpai pada ruang rawat intensif, ruangan non intensif memiliki lebih banyak Acinetobacter baumannii strain susceptible yang cenderung menunjukkan kepekaan tinggi terhadap berbagai antibiotik yang diuji. Strain MDR menunjukkan kepekaan yang baik terhadap amikacin, trimethoprim-sulfamethoxazole, tobramycin, ampicillinsulbactam, dan meropenem. Acinetobacter baumannii strain XDR hanya menunjukkan kepekaan yang masih baik terhadap amikacin.

\section{REFERENSI}

1. World Health Organization. Guidelines for the prevention and control of carbapenemresistant Enterobacteriaceae, Acinetobacter baumannii and Pseudomonas aeruginosa in health care facilities. Geneva: World Health Organization; 2017.

2. Manchanda V, Sanchaita S, Singh NP. Multidrug resistant Acinetobacter. Journal of Global Infectious Diseases. 2012; 2(3): 291-304.

3. Gonzalez-Villoria AM, Valverde-Garduno V. Antibiotic-Resistant Acinetobacter baumannii Increasing Success Remains a Challenge as a Nosocomial Pathogen . Journal of Pathogens. 2016;2016:1-10.

4. Barrie A, Gorman M. Acinetobacter baumannii-The New MRSA? Eplasty [Internet]. 2016;16:ic10. 
http://www.ncbi.nlm.nih.gov/pubmed/27011781\%0Ahttp://www.pubmedcentral.nih.gov/ar ticlerender.fcgi?artid=PMC4796877

5. Kuo HY, Chao $\mathrm{HH}$, Liao PC, Hsu L, Chang $\mathrm{KC}$, Tung $\mathrm{CH}$, et al. Functional characterization of Acinetobacter baumannii Lacking the RNA chaperone Hfq. Frontiers in Microbiology. 2017;8(Oct):1-12.

6. Montefour K, Frieden J, Hurst S, Helmich C, Headley D, Martin M, et al. Acinetobacter baumannii: An emerging multidrug-resistant pathogen in critical care. Critical Care Nurse. 2008;28(1):15-25.

7. Landman D, Quale JM, Mayorga D, Adedeji A, Vangala K, Ravishankar J, Flores C, Brooks S. Citywide clonal outbreak of multiresistant Acinetobacter baumannii and Pseudomonas aeruginosa in Brooklyn, NY. Archives of Internal Medicine . 2002;162: 1515-20.

8. Ayan M, Durmaz R, Aktas E, Durmaz B. Bacteriological, clinical and epidemiological characteristics of hospital-acquired Acinetobacter baumannii infection in a teaching hospital. Journal of Hospital Infection. 2003;54: 39-45.

9. Dijkshoorn L, Aucken H, Gerner-Smidt P, Janssen P, Kaufmann ME, Garaizar J, Ursing J, Pitt TL. Comparison of outbreak and nonoutbreak Acinetobacter baumannii strains by genotypic and phenotypic methods. Journal of Clinical Microbiology. 1996; 34:1519-1525.

10. Aygun G, Demirkiran O, Utku T, Mete B, Urkmez S, Yilmaz M, Yasar H, Dikmen Y, Oztürk R. Environmental contamination during a carbapenem-resistant Acinetobacter baumannii outbreak in an intensive care unit. Journal of Hospital Infection. 2002;52: 25962.

11. Willemsen I, Bogaers-Hofman D, Winters M, Kluytmans J. Correlation between antibiotic use and resistance in a hospital: temporary and ward-specific observations. Infection. 2009, 37(5): 432-7.

12. Peraturan Menteri Kesehatan No.8 Tahun 2015 Tentang Program Pengendalian Resistensi Antibiotik di Rumah Sakit.

13. Bergogne-Berezin E, Towner KJ. Acinetobacter spp. as nosocomial pathogens: microbiological, clinical, and epidemiological features. Clinical Microbiology Reviews. 1996;9:148-65.

14. Seifert H, Dijkshoorn L, Gerner-Smidt P, Pelzer N, Tjernberg I, Vaneechoutte M. Distribution of Acinetobacter species on human skin: comparison of phenotypic and genotypic identification methods. Journal of Clinical Microbiology. 1997;35: 2819-25.

15. Berlau J, Aucken H, Malnick H, Pitt T. Distribution of Acinetobacter species on skin of healthy humans. European Journal of Clinical Microbiology and Infectious Diseases. 1999;18:179-183.

16. Abbo A, Navon-Venezia S, Hammer-Muntz O, Krichali T, Siegman-Igra Y, Carmeli Y. Multidrug-resistant Acinetobacter baumannii. Emerging Infectious Diseases. 2005;11(1):22-9.

17. Daoud Z, Mansour N, Masri K. Synergistic Combination of Carbapenems and Colistin. Open Journal of Medical Microbiology. 2013;2013(December):253-8.

18. Mahdani W. Dua sisi antibiotik. Diunduh tanggal 16 januari 2015. http://aceh.tribunnews.com/2015/11/21/dua-sisi-antibiotik.

19. Broek PJV. 2015. Course Prudent Use of Antibiotiks. Surabaya.

20. Madigan MT, Martinko JM, Parker J. Brock biology of microorganisms. 14th edition. Book News, Inc., Portland. USA; 2015.

21. European Centre for Disease Prevention and Control (eCDC). Acinetobacter spp.; antimicrobial categories and agents used to define MDR, XDR and PDR, Antimicrobial Resistance and Healthcare-associated Infections Programme, viewed 28 September 2014, 
http://www.ecdc.europa.eu/en/activities/diseaseprogrammes/ARHAI/Documents/table5_Clinical_Microbiology_and_Infection.pdf.

22. Clinical and Laboratory Standards Institute (CLSI). Performance standards for antimicrobial susceptibility testing; twenty-fourth informational supplement, CLSI, Pennsylvania, US; 2017.

23. Yuan WL, Shen YJ, Deng DY. Sex bias of Acinetobacter baumannii nosocomial infection. American Journal of Infection Control. 2018;46: 957-60.

24. Xiao D, Wang L, Zhang D, Xiang D, Liu Q, Xing X. Prognosis of patients with Acinetobacter baumannii infection in the intensive care unit: A retrospective analysis. Experimental and Therapeutic Medicine. 2017; 13(4): 1630-1633.

25. Uwingabiye J, Lemnouer A, Baidoo S, Frikh M, Kasouati J, Maleb A, Benlahlou Y, Bssaibis F, Mbayo A, Doghmi N, Abouelalaa K, Baite A, Ibrahimi A, Elouennass M. Intensive care unit-acquired Acinetobacter baumannii infections in a Moroccan teaching hospital: epidemiology, risk factors and outcome. Germs. 2017 ; 7(4): 193-205.

26. Jung JY, Park MS, Kim SE, Park BH, Son JY, Kim EY, Lim JE, Lee SK, Lee SH, Lee KJ, Kang YA, Kim SK, Chang J, Kim YS. Risk factors for multi-drug resistant Acinetobacter baumannii bacteremia in patients with colonization in the intensive care unit. BMC Infectious Diseases. 2010; (2010): 10:228.

27. Peleg AY, Seifert H, Paterson DL. Acinetobacter baumannii: Emergence of a successful pathogen. Clinical Microbiology Reviews. 2008;21(3):538-82.

28. Rodríguez-Baño J, Martí S, Soto S, Fernandez-Cuenca F, Cisneros JM, Pachon J, Pascual A, Martínez-Martínez L, McQueary C, Actis LA, Vila J, Spanish Group for the Study of Nosocomial Infections (GEIH). Biofilm formation in Acinetobacter baumannii: associated features and clinical implications. Clinical Microbiology and Infection. 2008; 14: 276-278.

29. Kaplan JB. Antibiotic-induced biofilm formation. The International Journal of Artificial Organs. 201; 34: 737-751. 